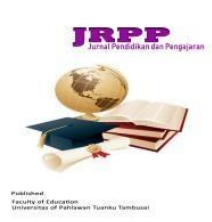

Jurnal ReviewPendidikan dan Pengajaran

http://journal.universitaspahlawan.ac.id/index.php/jrpp

Volume 2 Nomor 2, Desember 2019

P-2655-710X e-ISSN 2655-6022
Submitted : 26/11/2019

Reviewed :07/12/2019

Accepted :10/12/2019

Published :28/12/2019
Novelina Andriani Zega ${ }^{1}$

\section{PENGARUH PENGGUNAAN TAKTIK MENGAJAR PUNGGUNG DENGAN PUNGGUNG TERHADAP HASIL BELAJAR BIOLOGI SMA SWASTA KRISTEN BNKP GUNUNGSITOLI}

\begin{abstract}
Abstrak
Penelitian ini bertujuan untuk mengetahui pengaruh penggunaan taktik mengajar Punggung dengan Punggung terhadap hasil belajar Biologi siswa pada materi sistem reproduksi di kelas XI SMA Swasta Kristen BNKP Gunungitoli . Penelitian ini merupakan jenis penelitian eksperimen. Populasi dalam penelitian ini terdiri atas 2 kelas dan sampelnya ada 2 kelas. Hasil pengujian data diperoleh nilai rata rata untuk hasil belajar siswa yang diberi pengajaran dengan menggunakan taktik mengajar Punggung dengan Punggung 76,59 dan nilai rata-rata yang diberi pembelajaran konvensional 68,12. Dari hasil pengujian hipotesis diperoleh $t$ hitung $>\mathrm{t}$ tabel yaitu 4,57>2,372 pada taraf signifikan $\alpha=0,01$ hal ini berarti Ha diterima yang berarti ada pengaruh yang signifikan dalam hasil belajar biologi siswa antara kelas Punggung dengan Punggung dan kelas konvensional.
\end{abstract}

Kata Kunci: Hasil Belajar, Biologi

\title{
Abstract
}

The purpose of this research is to know the influence of teaching tactics Back to Back towards the result of student's biology learning on reproduction system at class XI SMA Swasta Kristen BNKP Gunungsitoli. The kind of research is experiment. The population in this study consists of 4 classes and the sample is 2 classes. The result of data analysis obtained average value for student learning outcomes are given instruction by using the teaching tactics back with back 76,59 and the average value of a given conventional learning 68,12. From the result obtained by testing the hypothesis t account > ttable is 4,57 > 2,372 at a significant level $\alpha=0,01$ this means Ha is accepted, which means there is a significant influence in learning outcomes between classes biology students back with back and conventional classes.

Keywords: Learning Outcomes, Biology

\footnotetext{
${ }^{1}$ Prodi Pendidikan Biologi, IKIP Gunungsitoli Alamat email: andrianizega84@gmail.com
} 


\section{PENDAHULUAN}

Pendidikan yang diselenggarakan dengan baik dan bermutu akan menghasilkan manusia-manusia yang tangguh bagi pembangunan nasional. Meningkatkan mutu pendidikan adalah menjadi tanggungjawab semua pihak yang terlibat dalam pendidikan terutama bagi guru, yang merupakan ujung tombak dalam pendidikan. Guru adalah orang yang paling berperan dalam menciptakan sumber daya manusia yang berkualitas yang dapat bersaing di jaman pesatnya perkembangan teknologi. Tenaga pendidik khususnya guru sangat memerlukan aneka ragam pengetahuan dan keterampilan keguruan yang memadai dalam arti sesuai dengan tuntutan zaman dan kemajuan sains dan teknologi (Syah, 2010).

Kebijakan pemerintah dalam meningkatkan mutu pendidikan tidak akan tercapai bila upaya itu tidak akan terkait dengan perbaikan pembelajaran di dalam kelas. Pembelajaran merupakan inti kegiatan akademis di sekolah. Oleh karena itu seorang guru profesional sebelum menyampaikan materi akan mempertimbangkan model, pendekatan dan metode mengajar yang digunakan, supaya peserta didik benar-benar memperoleh kecakapan dan pengetahuan. Upaya yang dilakukan dalam menghadapi masalah tersebut yaitu guru dituntut agar lebih aktif dan professional dalam melakukan tugasnya terlebih dalam melaksanakan proses belajar mengajar didalam kelas, serta harus mampu menerapkan model pembelajaran atau gaya mengajar yang bervariasi agar mengurangi tingkat kejenuhan belajar siswa. Proses pembelajaran merupakan salah satu bentuk kegiatan yang mengarahkan peserta didik untuk dapat mencapai belajar penuh makna. Kegiatan pembelajaran memiliki tujuan yang pada akhirnya siswa diharapkan mengalami perubahan pengetahuan (kognitif), perubahan sikap (afektif), dan perubahan tingkah laku (psikomotor)

Proses pembelajaran tidak terlepas dari peran guru, tetapi guru hanya berperan sebagai fasilitator dan bukan satu satunya sumber informasi bagi siswa. Sebaliknya siswa sebagai subyek proses pembelajaran diberi keleluasaan yang sangat luas untuk menentukan pencapaian kompetensi yang harus ia raih. Guru mengajar dengan merangsang, membimbing, dan mengarahkan siswa mempelajari bahan pelajaran sesuai tujuan pembelajaran. Tujuan belajar pada umumnya adalah agar bahan pelajaran yang disampaikan dikuasai sepenuhnya oleh semua siswa. Tercapai atau tidaknya suatu tujuan pembelajaran sangat dipengaruhi oleh model atau taktik belajar yang diterapkan oleh guru. Semakin tepat model maupun taktik yang digunakan maka semakin efektif pula pencapaian tujuan pembelajaran yang diharapkan (Nurohmawaty, 2008).

Variasi mengajar merupakan salah satu usaha guru dalam menciptakan keaktifan siswa serta menumbuhkan minat belajar siswa. Guru yang professional akan selalu berpikir bagaimana caranya menciptakan suasana kelas yang aktif dalam belajar sehingga indah dilihat. Cara yang sering dilakukan oleh guru misalnya menerapkan model-model pembelajaran kooperatif disetiap kegiatan belajar mengajar berlangsung, adapun beberapa model pembelajaran yang sering dilaksanakan adalah picture and picture, debat, listening team,dsb. Namun bukan hanya model pembelajaran saja yang 
bisa diterapkan oleh guru di dalam kelas tetapi masih ada cara yang lain, misalnya menerapkan suatu taktik mengajar yang pastinya berbeda dengan model pembelajaran. Keunggulan dari taktik mengajar terdapat pada kemudahannya dalam proses pelaksanaannya. Contoh dari taktik mengajar yaitu punggung dengan punggung, pelaksanaannya mudah serta banyak melatih siswa untuk mengingat, mendeskripsikan dan melatih kemampuan siswa untuk menyampaikan ulang materi pelajran. Alasan tersebut yang membuat penulis tertarik untuk menggunakan suatu taktik mengajar dalam penelitiannya.

Berdasarkan studi pendahuluan yang dilakukan di SMA Swasta Kristen BNKP Gunungsitoli ,mengungkapkan bahwa hasil belajar siswa yang dicapai di kelas XI tergolong rendah. Selanjutnya dari hasil observasi tersebut, guru yang diwawancarai mengatakan pengaruh terbesar terhadap hasil belajar siswa terdapat pada diri mereka sendiri, yang artinya faktor internal yang berperan penting, sehingga ada anggapan dari siswa bahwa sekolah hanya untuk mendapatkan ijazah. Dorongan orang tua berada di posisi kedua, kurangnya peran orang tua untuk memberikan motivasi kepada siswa agar mau bersekolah menjadi beban tersendiri bagi siswa, sehingga menimbulkan kemalasan untuk menerima pelajaran yang diberikan oleh guru. Faktor yang ketiga tidak adanya variasi gaya dalam mengajar yang dilakukan oleh guru menjadi suatu alasan bagi mereka untuk mengatakan jenuh dalam mengikuti pembelajaran di kelas.

Beberapa faktor tersebut yang sangat mempengaruhi hasil belajar siswa, sehingga untuk memperoleh nilai ketuntasan atau pencapaian KKM yang nilainya mencapai 75 sangatlah sulit bagi mereka. Adapun siswa yang mampu melampaui batas KKM sekitar 30\% saja dan mereka yang lulus bisa dipastikan tidak berada di dalam faktor-faktor tersebut, selebihnya $70 \%$ dianggap gagal dan berada di dalam faktor-faktor penghambat.

\section{METODE}

Penelitian ini akan dilaksanakan di SMA Swasta Kristen BNKP Gunungsitoli denga menggunakan metode penelitian eksperimen dengan paradigma kuantitatif. Sebagai penelitian kuantitatif, penelitian ini berupaya membuktikan kebenaran teori- teori tentang model pembelajaran taktik punggung dengan punggung dan pengaruhnya terhadap hasil belajar siswa. Penelitian ini menggunakan metode penelitian eksperimen murni dengan memberikan perlakuan berupa proses pembelajaran menggunakan taktik pembelajaran punggung dengan punggung. Ada beberapa desain penelitian eksperimen murni, tetapi yang digunakan dalam penelitian ini adalah randomized pretets-postest experiment - control group design seperti tertera pada tabel berikut: 
Tabel 3 Desain Penelitian

\begin{tabular}{|c|c|c|c|}
\hline Kelas & Pre-test (tes awal) & Perlakuan & Post-test (tes akhir) \\
\hline Experimental Group & $\mathrm{T}_{1(\mathrm{E})}$ & $\mathrm{P}_{(\mathrm{E})}$ & $\mathrm{T}_{2(\mathrm{E})}$ \\
\hline Control Group & $\mathrm{T} 1(\mathrm{C})$ & - & $\mathrm{T}_{2(\mathrm{C})}$ \\
\hline
\end{tabular}

Keterangan :

$\mathrm{T} 1(\mathrm{E})=$ Tes awal pada kelas eksperimen

$\mathrm{T} 1(\mathrm{C})=$ Tes awal pada kelas kontrol

$\mathrm{P}(\mathrm{E}) \quad=$ Perlakuan pada kelas eksperimen menggunakan pendekatan interaktif

$=$ Metode pembelajaran yang diperlakukan pada kelas kontrol adalah pembelajaran konvensional.

$\mathrm{T} 2(\mathrm{E})=$ Tes akhir pada kelas eksperimen

$\mathrm{T} 2(\mathrm{C})=$ Tes akhir pada kelas kontrol

\section{HASIL DAN PEMBAHASAN}

\section{Hasil Belajar}

Berdasarkan hasil penelitian maka diperoleh data pretes seperti pada Tabel 4.1. Pada data tersebut dapat dilihat rata-rata nilai pretes kelas kontrol 37,44. Nilai tertinggi pada kelas kontrol 60 dengan frekuensi 1 dan nilai terendah 23,33 dengan frekuensi 1. Standar deviasi untuk nilai pre-test kelas kontrol 8,74 dan varians 72,08. Dari tabel yang sama kita dapat memperoleh rata-rata nilai pre tes kelas eksperimen 42,28. Nilai tertinggi pada kelas eksperimen 66,67 dengan frekuensi 1 dan nilai terendah 26,67 dengan frekuensi 4. Standar deviasi untuk nilai pre tes kelas eksperimen 9,35 dan varians 87,42

Untuk data postes maka diperoleh data hasil belajar seperti pada Tabel 4.1. Dari tabel tersebut dapat dilihat nilai rata-rata kelas kontrol 68,12 dengan nilai tertinggi pada kelas kontrol 86,67 dengan frekuensi 1 dan nilai terendah 53,33 dengan frekuensi 2. Standar deviasi untuk nilai post-test kelas kontrol 8,74 dan variansnya 76,38 yang apabila dihubungkan dengan KKM biologi yaitu 65 maka terlihat jelas ada 15 orang yang tidak mencapai KKM. Dari tabel yang sama diperoleh nilai rata-rata kelas eksperimen 76,59 dengan nilai tertinggi pada kelas eksperimen 93,34 dengan frekuensi 1 dan nilai terendah adalah 60 dengan frekuensi 1. Standar deviasi untuk nilai post-test kelas eksperimen 8,07 dan varians 65,12.

Bila dihubungkan dengan KKM biologi yaitu 65 maka dapat dikatakan bahwa hasil belajar biologi siswa yang diberi perlakuan dengan taktik mengajar Punggung dengan Punggung mendapat nilai rata-rata diatas KKM atau dengan kata lain ketercapaian siswa terhadap indikator pembelajaran yang telah dibuat tercapai. 
Tabel 4.1. Data Hasil Belajar

\begin{tabular}{|c|c|c|c|c|c|c|c|}
\hline \multicolumn{4}{|c|}{ Kelas Kontrol } & \multicolumn{4}{c|}{ Kelas Eksperimen } \\
\hline \multicolumn{2}{|c|}{ PreTes } & \multicolumn{2}{c|}{ PosTes } & \multicolumn{2}{c|}{ PreTes } & \multicolumn{2}{c|}{} \\
\hline Nilai & Frekuensi & Nilai & Frekuensi & Nilai & Frekuensi & Nilai & Frekuensi \\
\hline 23,33 & 1 & 53,33 & 2 & 26,67 & 4 & 60 & 1 \\
\hline 26,67 & 6 & 56,67 & 3 & 30 & 3 & 63,34 & 2 \\
\hline 30 & 4 & 60 & 5 & 33,33 & 1 & 66,67 & 4 \\
\hline 33,33 & 4 & 63,33 & 5 & 36,67 & 3 & 70 & 4 \\
\hline 36,67 & 8 & 66,67 & 7 & 40 & 11 & 73,34 & 7 \\
\hline 40 & 3 & 70 & 6 & 43,33 & 4 & 76,67 & 7 \\
\hline 43,33 & 8 & 76,67 & 5 & 46,67 & 4 & 80 & 4 \\
\hline 46,67 & 1 & 80 & 3 & 50 & 5 & 83,34 & 6 \\
\hline 50 & 1 & 83,33 & 2 & 53,33 & 2 & 86,67 & 2 \\
\hline 53,33 & 2 & 86,67 & 1 & 56,67 & 3 & 90 & 3 \\
\hline 60 & 1 & & & 66,67 & 1 & 93,34 & 1 \\
\hline Jlh & $\mathbf{3 9}$ & Jlh & $\mathbf{3 9}$ & Jlh & $\mathbf{4 1}$ & Jlh & $\mathbf{4 1}$ \\
\hline Rata2 & $\mathbf{3 7 , 4 4}$ & Rata2 & $\mathbf{6 8 , 1 2}$ & Rata2 & $\mathbf{4 2 , 2 8}$ & Rata2 & $\mathbf{7 6 , 5 9}$ \\
\hline SD & $\mathbf{8 , 7 4}$ & SD & $\mathbf{8 , 7 4}$ & SD & $\mathbf{9 , 3 5}$ & SD & $\mathbf{8 , 0 7}$ \\
\hline Varians & $\mathbf{7 2 , 0 8}$ & Varians & $\mathbf{7 6 , 3 8}$ & Varians & $\mathbf{8 7 , 4 2}$ & Varians & $\mathbf{6 5 , 1 2}$ \\
\hline
\end{tabular}

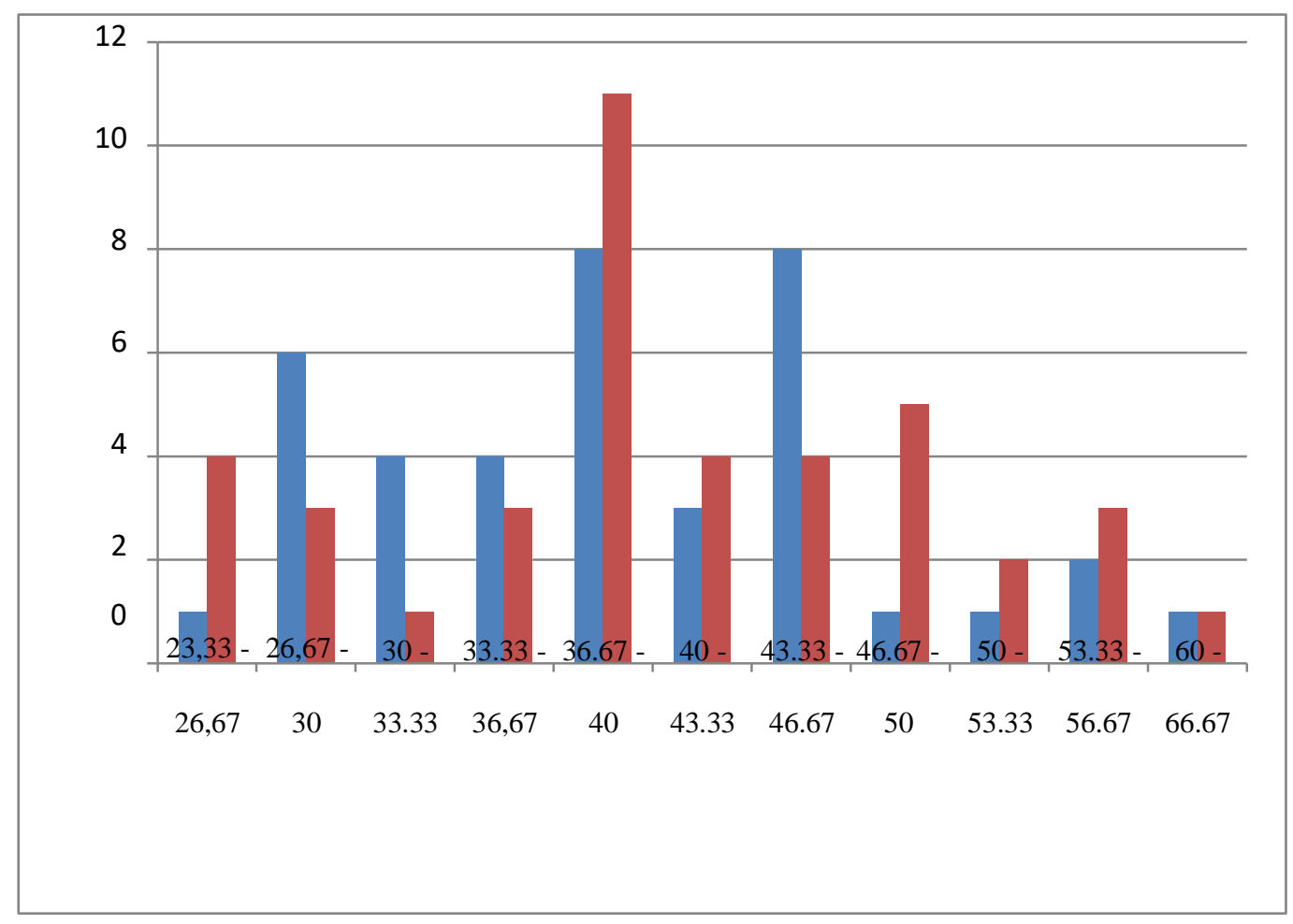

Gambar 4.1. Grafik Perbandingan antara Nilai Pretes Konvensional dengan Punggung dengan Punggung 


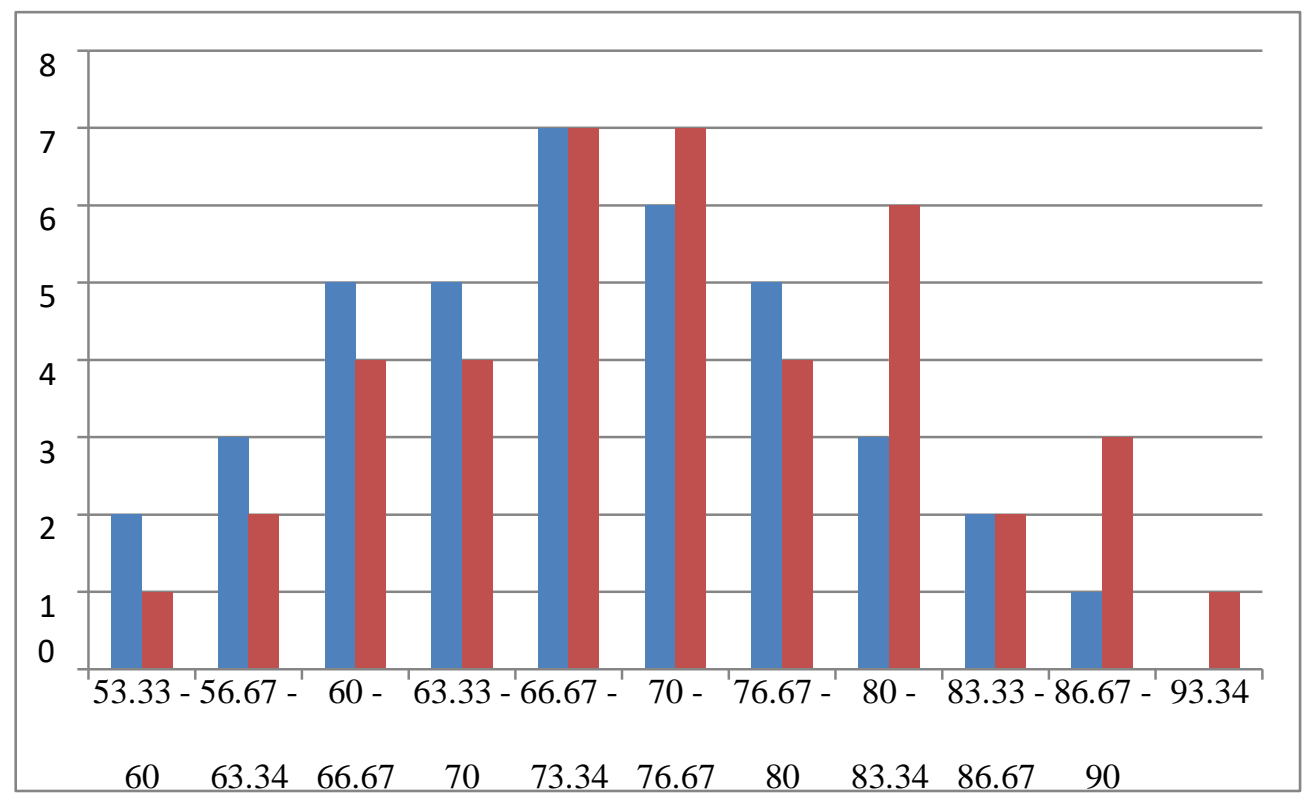

Gambar 4.2. Grafik Perbandingan antara Nilai Postes

Konvensional dengan Punggung dengan Punggung

Berdasarkan hasil data pretes yang menunjukkan nilai rata-rata siswa adalah 42,28 untuk kelas eksperimen dan 37,44 untuk kelas kontrol, maka dapat dilanjutkan dengan uji normalitas dan uji homogenitas. Pada uji normalitas data kedua kelas berdistribusi normal dan untuk uji homogenitas data kedua kelas homogen. Untuk hasil uji kemampuan akhir diperoleh data yang menunjukkan nilai rata-rata siswa pada materi sistem reproduksi pada kelas kontrol adalah 68,12 dan pada kelas eksperimen 76,59. Kemudian dilanjutkan dengan pengujian normalitas dan homogenitas. Pada uji normalitas data kedua kelas berdistribusi normal dan untuk uji homogenitas data kedua kelas homogen. Langkah selanjutnya dilakukan uji t untuk melihat perbedaan nilai post- test kedua kelas, berdasarkan uji $\mathrm{t}$ yang dilakukan diperoleh thitung $=4,57>$ ttabel=2,372 pada taraf signifikan $\alpha=0,01$ (99\%), maka dapat dikatakan Ho ditolak dan Ha diterima. Berdasarkan uji t yang dilakukan berarti terdapat pengaruh penggunaan taktik mengajar Punggung dengan Punggung terhadap hasil belajar biologi siswa pada materi pokok sistem reproduksi kelas XI SMA Swasta Kristen BNKP Gunungsitoli Tahun Pembelajaran 2017/2018.

Dengan penggunaan taktik mengajar Punggung dengan Punggung yang dilakukan oleh guru dapat saling menguntungkan, dimana antara siswa yang berprestasi rendah dengan siswa yang berprestasi tinggi yang bekerja sama dalam melaksanakan proses pembelajaran, siswa berkemampuan tinggi akan semakin lebih baik dalam mengulang pelajaran dan siswa yang berkemampuan rendah akan menjadi baik dalam mengingat pelajaran. Hal ini berarti seluruh siswa yang secara akademik mendapat 
keuntungan karena bekerjasama dalam melaksanakan KBM dengan menggunakan taktik mengajar Punggung dengan Punggung.

Apabila diperhatikan pada data terdapat peningkatan hasil belajar, hal ini dilihat dari nilai rata-rata yang diperoleh siswa. Pada metode konvensional rata-ratanya adalah 68,12 dan pada taktik mengajar Punggung dengan Punggung nilai rata-ratanya adalah 76,59. Peningkatan ini mungkin terjadi karena dengan taktik mengajar yang dilakukan siswa dapat lebih mudah mengulang pelajaran dan mampu memahami konsep lebih jelas sebab adanya kesempatan untuk berlatih dan berbagi pemahaman dengan teman sekelompok serta memiliki kesempatan langsung untuk dibimbing gurunya sendiri ketika kegiatan inti berlangsung.

Taktik mengajar Punggung dengan Punggung ini mampu menumbuhkan minat membaca, mengingat dan memotivasi diri sendiri dalam belajar sehingga berdampak pada meningkatnya hasil belajar biologi, baik secara psikomotorik, afektif dan kognetif. Dari tinjuan psikologis, terdapat dasar teoritis yang kuat yang menyatakan bahwa metode pembelajaran kooperatif yang menggunakan tujuan kelompok dan tanggung jawab individual akan meningkatkan pencapaian prestasi siswa.

Dua teori utama yang mendukung pembelajaran kooperatif adalah teori motivasi dan teori kognitif. Menurut Slavin (2011), perspektif motivasional pada pembelajaran kooperatif terutama memfokuskan pada penghargaan atau struktur tujuan di mana para siswa bekerja. Deutsch (1949) dalam Slavin (2011) mengidentifikasikan tiga struktur tujuan dalam pembelajaran kooperatif, yaitu: (1) Kooperatif, di mana usaha berorientasi tujuan dari tiap individu memberi konstribusi pada pencapaian tujuan anggota yang lain.(2) Kompetitif, di mana usaha berorientasi tujuan dari tiap individu menghalangi pencapaian tujuan anggota lainnya.(3) Individualistik, di mana usaha berorientasi tujuan dari tiap individu tidak memiliki konsenkuensi apa pun bagi pencapaian tujuan anggota lainnya.

Dari perspektif motivasional, struktur tujuan taktik mengajar Punggung dengan Punggung adalah menciptakan sebuah situasi di mana satu-satunya cara pasangannya bisa meraih tujuan pribadi adalah jika kelompok belajarnya sukses. Oleh karena itu, siswa harus kreatif dan mampu berimajinasi demi menyaingi kemampuan pasangannya, dengan tujuan untuk memacu minat temannya menjadi lebih baik lagi serta terlihat kemampuan yang seimbang. Sedangkan dari perspektif kognitif dapat dilihat bahwa taktik mengajar yang dilaksanakan dapat menekankan pada pengaruh dari kerja sama terhadap pencapaian tujuan pembelajaran. Asumsi dasar dalam pembangunan kognitif ini adalah bahwa interaksi di antara para siswa berkaitan dengan tugas-tugas yang sesuai mengingkatkan penguasaan mereka terhadap konsep kritik (Zagoto, dkk., 2019).

Pengelompokan siswa yang heterogen mendorong interaksi yang kritis dan saling mendukung bagi pertumbuhan dan perkembangan pengetahuan atau kognitif. Penelitian psikologi kognitif menemukan bahwa jika informasi ingin dipertahankan di dalam memori dan berhubungan dengan informasi yang sudah ada di dalam memori, 
orang yang belajar harus terlibat dalam semacam pengaturan kembali kognitif, atau elaborasi dari materi. Salah satu cara elaborasi yang paling efektif adalah menjelaskan materinya kepada orang lain (Slavin, 2011). Karakteristik inilah yang menjadi penekanan dalam proses implementasi suatu taktik mengajar dan sangat mendukung ketercapaian tujuan pembelajaran (Zagoto, dkk., 2018; Sarumaha, 2018; Dakhi, O., 2013)

Secara psikologis, lingkungan belajar yang diciptakan guru dapat direspon beragam oleh siswa sesuai dengan modalitas mereka. Dalam hal ini, pembelajaran dengan taktik mengajar Punggung dengan Punggung memiliki beberapa pengaruh terhadap pencapaian belajar siswa yang yang juga dapat dikatakan sebagai keunggulan pembelajaran Punggung dengan Punggung, diantaranya (1) mampu melatih pola berpikir siswa dengan baik, (2) meningkatkan kecerdasan emosional siswa, (3) mampu melatih kemandirian siswa dalam belajar, (4) siswa terbantu dalam hal mengingat dan mengulangi materi pelajaran (Ginnis,2008).

\section{SIMPULAN}

Berdasarkan dari hasil pembahasan dalam penelitian ini dapat disimpulkan bahwa terdapat pengaruh penggunaan taktik mengajar Punggung dengan Punggung terhadap hasil belajar biologi siswa pada materi sistem reproduksi di kelas XI SMA Swasta Kristen BNKP Gunungsitoli ,dimana pembelajaran dengan menggunakan taktik mengajar Punggung dengan Punggung lebih tinggi hasilnya dibandingkan dengan pembelajaran konvensional di SMA Swasta Kristen BNKP .

\section{SARAN}

Berdasarkan hasil penelitian ini penulis memberikan saran-saran sebagai berikut:

1. Perlunya para guru memperhatikan tampilan gaya mengajarnya, agar siswa berpersepsi positif terhadap guru, karena dengan adanya variasi mengajar siswa akan lebih aktif lagi dalam mengikuti pelajaran yang diberikan oleh guru.

2. Bagi guru dan calon guru, agar menjadikan taktik mengajar Punggung dengan Punggung dan taktik mengajar lainnya sebagai salah satu alternatif pembelajaran biologi.

\section{DAFTAR PUSTAKA}

Arikunto, S., (2002), Prosedur Penelitian, Penerbit Bumi Aksara, Jakarta.

Arikunto, S., (2011), Dasar-dasar Evaluasi Pendidikan, Penerbit Rineka Cipta, Jakarta.

Dakhi, O. "Aplikasi Pendeteksian Kerusakan File Akibat Virus Dengan Menggunakan Metode Heuristic." Pelita Informatika Budi Darma, vol. 4, no. 1, pp. 35-41, 2013.

Dakhi, O. 2013. Belajar Javascript Dengan Mudah Dan Detail. Jakarta: Dapur Buku. pp. 1-202.

Emawati., (2009), http://dir/BSE (Buku Sekolah Elektronik) 2013/02/23/ Gambar tentang biologi-organ reproduksi laki-laki (diakses 28 April 2018).

Fakultas Matematika dan Ilmu Pengetahuan Alam Universitas Negeri Medan, (2011), Buku Pedoman Penulisan Proposal dan Skripsi Mahasiswa Program Studi Pendidikan, FMIPA Unimed. 
Ginnis, P., (2008), Trik dan Taktik Mengajar, Penerbit Indeks, Jakarta.

Nurohmawaty, R., (2008), Perbandingan Hasil Belajar Siswa Menggunakan Pembelajaran Cycle Learning Dengan Konvensional Pasa Materi Pokok Ekosistem di Kelas X Madrasah Aliyah Negeri 1 Medan, Skripsi FMIPA Unimed, Medan.

Psychologymania., (2012), http://www.psychologymania. com /2012/06/ sistem reproduksi-pria.html (diakses 27 April 2019).

Sarumaha, R., Harefa, D., \& Zagoto, Maria M. (2018). Upaya Meningkatkan Kemampuan Pemahaman Konsep Geometri Transformasi Refleksi Siswa Kelas XII-IPA-B SMA Kampus Telukdalam Melalui Model Pembelajaran Discovery Learning Berbantuan Media Kertas Milimeter. Jurnal Education and development, Vol.6 No.1, 90-96. https://doi.org/10.37081/ed.v6i1.668

Sinaga, S., (2012), Pengaruh Model Pembelajaran Kooperatif Tipe TGT Terhadap Hasil Belajar Siswa Pada Pokok Bahasan Sistem Eksresi di Kelas XI SMA Negeri 1 Pangururan T.P 2011/2012. Skripsi FMIPA Unimed, Medan.

Slameto., (2010), Belajar dan Faktor-faktor yang Mempengaruhinya, Penerbit Rineka Cipta, Jakarta.

Slavin., (2011), Cooperative Learning, Teori, Riset dan Praktik, Nusa Media, Bandung.

Sudjana, N., (2008), Metoda Statistika, Penerbit Tarsito, Bandung.

Syah, M., (2010), Psikologi Pendidikan, Remaja Rosdakarya, Bandung.

Zagoto, Maria M., Yarni, Nevi; Dakhi, O. (2019). Perbedaan Individu dari Gaya Belajarnya Serta Implikasinya Dalam Pembelajaran. Jurnal Review Pendidikan dan Pengajaran, 2(2), 259265.

Zagoto, Maria M. \& Dakhi, O (2018). Pengembangan Perangkat Pembelajaran Matematika Peminatan Berbasis Pendekatan Saintifik Untuk Siswa Kelas XI Sekolah Menengah Atas. Jurnal Review Pendidikan dan Pengajaran, 1(1), 157-170.

Zagoto, Maria M. (2018). Pengembangan Perangkat Pembelajaran Matematika Berbasis Realistic Mathematic Educations Untuk Siswa Kelas V Sekolah Dasar, Jurnal Education And Development, vol. 3, no. 1, p. 53, Feb. 2018. https://doi.org/10.37081/ed.v3i1.139

Zubaidah, S., (2010). Restrukturisasi Pemahaman Berbagai Istilah Pada Penulisan Komponen Metode Dalam Rencana Pelaksanaan Pembelajaran, Jurnal FMIPA UNM, Malang. 